\title{
Large-cell Neuroendocrine Carcinoma of the Endometrium in Myomatous Uterus
}

\author{
Spasimir T. Shopov ${ }^{1}$, Benyamin L. Anavi², Dobrin K. Krastev ${ }^{3}$ \\ ${ }^{1}$ Department of General and Clinical Pathology, Medical University of Plovdiv, Plovdiv, Department of Pathology, Parvomai Ltd Hospital, Parvomai, \\ Bulgaria \\ 2 Department of Pathology, Thorax Dr Sava Boyadzhiev Hospital of Obstetrics and Gynecology, Plovdiv, Bulgaria \\ ${ }^{3}$ Department of Obstetrics and Gynecology, Parvomai Ltd Hospital, Parvomai, Bulgaria
}

Corresponding author: Spasimir T. Shopov, Department of Clinical Pathology, Medical University of Plovdiv, 15A Vassil Aprilov Blvd., 4000 Plovdiv, Bulgaria; E-mail: sshopov1@abv.bg; Tel.: 0878657256

Received: 07 Dec 2018 Accepted: 01 Aug 2019 Published: 30 June 2020

Citation: Shopov ST, Anavi BL, Krastev DK. Large-cell neuroendocrine carcinoma of the endometrium in myomatous uterus. Folia Med (Plovdiv) 2020;62(2):412-17. doi: 10.3897/folmed.62.e49815.

\begin{abstract}
Large-cell neuroendocrine carcinoma of the endometrium is an insufficiently researched aggressive tumor with a short survival regardless of the treatment type.

We present here the $38^{\text {th }}$ consecutive case of literature reported cases of large cell neuroendocrine carcinoma of the endometrium (positive for synaptophysin, CD56, chromogranin A, p53, and Vimentin) found in the myomatous uterus of a 76-year-old woman.

We also describe in the study the morphological algorithm for differentiation of malignant blastomas with small (under $10 \%$ ) neuroendocrinal component.

Accumulated clinical and morphological evidence raises the question whether the large-cell and the small-cell neuroendocrine carcinomas are just different variations according to their histology and topical occurrence (uterine body/cervix) or they are just independent forms with their respective clinical signs, morphology, treatment, and prognosis.
\end{abstract}

\section{Keywords}

immunohistochemistry, large-cell neuroendocrine carcinoma of the endometrium, myomatous uterus.

\section{INTRODUCTION}

The first case of large-cell neuroendocrine carcinoma of the endometrium (LCNEC) was reported in 2004 by Y. Erhan et al. ${ }^{1}$ on the basis of histological and immunohistochemical resemblance with the neuroendocrine carcinomas (NEC) of the lungs. As a rule NEC express at least one neuroendocrine marker (chromogranin, synaptophysin, NSE or CD56, which is less specific) in more than $10 \%$ of tumor cells. In the past, these were considered undifferentiated tumors of the uterine body. In 2017, Yi-An Tu et al. ${ }^{2}$ summarized the available data for 16 cases of LCNEC in the endometrium. However, this number does not include the 15 individual LCNEC cases from the overview of Pocrnich CE et al. ${ }^{3}$ We have found in literature another 6 published cas$\mathrm{es}^{4-9}$, so the present case turns out to be number 38 in the series of cases of LCNEC reported in the literature. Broadening the knowledge for these rare tumors could have a significant role for their early diagnosis and treatment.

\section{CASE REPORT}

A 76-year-old woman with a 10-year history of uterine leiomyoma and clinically monitored for the last 3 years, presented with moderate vaginal bleeding and dull abdominal pain in last three months. She also had compensated type 2 diabetes mellitus and slight anemia. Tumor markers $C A$

Copyright by authors. This is an open access article distributed under the terms of the Creative Commons Attribution License (CC-BY 4.0) 
125 before and after surgery were within the normal range. Gynecological status: enlarged uterus, probably a consequence of the leiomyoma. Trans-vaginal ultrasound tests showed uneven thickening of the uterine wall - leiomyomatous nodes and $5 \times 4 \mathrm{~cm}$ formation in the fundus suspicious for a malignant process. The sample material taken during 2 curettages was insufficient because the procedures were hampered by the leiomyomas (cervical mucus without neoplastic infiltration).

We performed total hysterectomy, salpingo-oophorectomy with a dissection of the pelvis lymph nodes and part of the omentum. The post-surgical positron emission tomography (PET) identified increased absorption of fluorodeoxyglucose in the right side of the para-aortic, paracaval and iliac lymph nodes (Fig. 1).

Macroscopically, the uterus $(10 \times 12 \times 8 \mathrm{~cm})$ was with three

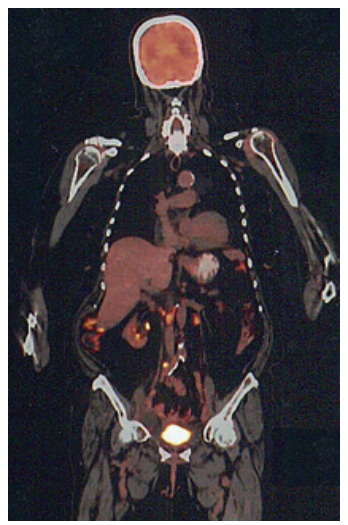

Figure 1. Postsurgical positron emission tomography (PET): increased absorption of fluorodeoxyglucose in the right side of the paraaortic, paracaval and iliac lymph nodes.

fully distinct thick whitish bundle-structured nodes. The largest of these $(8 \times 8 \times 5 \mathrm{~cm})$ spread in one corpus and part of the fundus. In close proximity, there was an exophytic tumor formation $(6 \times 5 \mathrm{~cm})$ with a colorful cut surface, which spread to over half of the myometrium's thickness (Figs 2a, b). The cervix, uterine tubes and ovaries were atrophic. There were three lymph nodes: two on the right, $(3 \times 2 \mathrm{~cm}$ and $2 \times 1 \mathrm{~cm})$, and one on the left $(3 \times 2 \times 1 \mathrm{~cm})$.

Histological findings (H-E) (Fig. 3): The main compact tumor mass had a smooth border and was distinctly separated from an adjacent leiomyoma by a band of normal myometrium. Perivascular on the leiomyoma's outline, however, there was a thin line of hyperchromic tumor mass, a manifestation of infiltrative growth (a). In the diffused tumor structure there were predominantly cells with large oval vesicular nuclei with distinct nucleoli. The nuclei prevailed in size over the pink cytoplasm, which faded into the cytoplasm of the adjacent cells. In the peripheral areas, there were some cells with more hyperchromic nuclei and rough grainy chromatin, many of which were binuclear. There was a significant amount of mitosis. In the polymorphic picture, there were also miniscule lymphocyte-like cells (especially on the border of the myometrium) and cells with eosinophilic cytoplasm (b). There were no glands, but at some places there were traces of nest-like structures (c). There were focal necroses regardless of the fine capillarisation of the tumor parenchyma $(\boldsymbol{d})$.

The leiomyomas had a typical bundle growth, with haphazard hyalinization, without any hypercellularity. There was no established infiltration from the main tumor inside them.

The endometrium had a cystic atrophy. The cervix was with epidermization of the cervical gland, without any tumor infiltration. Fallopian tubes had fibrosis and paratubal cysts. The ovaries were with white bodies. There were three lymph nodes with massive metastasis of the abovementioned structure. The omentum was without neoplastic infiltration.

Immunohistochemistry (Dako, Glostrup, Denmark) (Fig. 4): Nearly 40\% of the cells from the main tumor were positive for synaptophysin, CD56, chromogranin A, Vimentin and $p 53$. They showed high prolific activity (Ki67 over $75 \%)$.

The malignant tumor was negative for CK AE1/AE3,

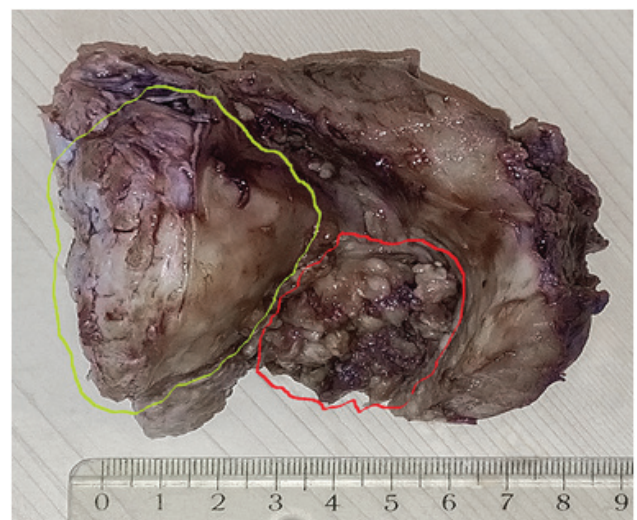

$2 a$

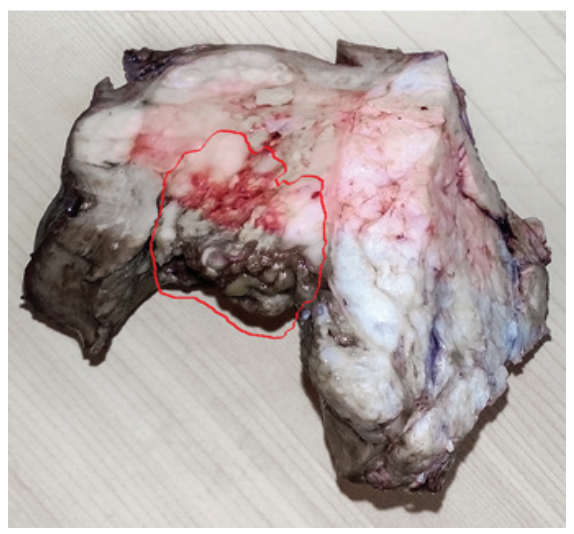

$2 b$

Figure 2. General overview of the tumors in the uterine body (red arrow and red outline - LCNEC; black arrows and black outline leiomyomas): a. A view from the uterine cavity; b. Cut surfaces. 


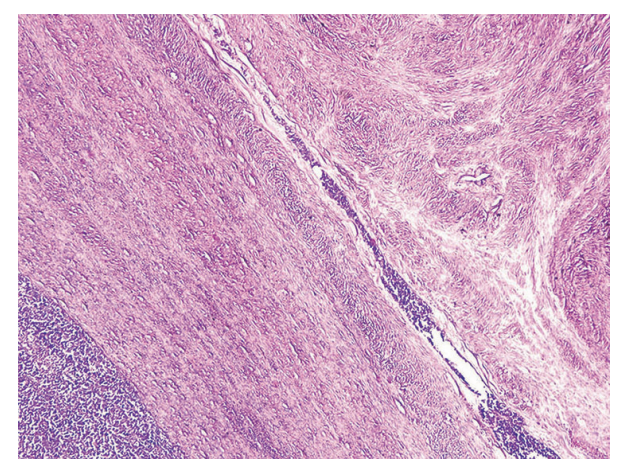

$3 a$

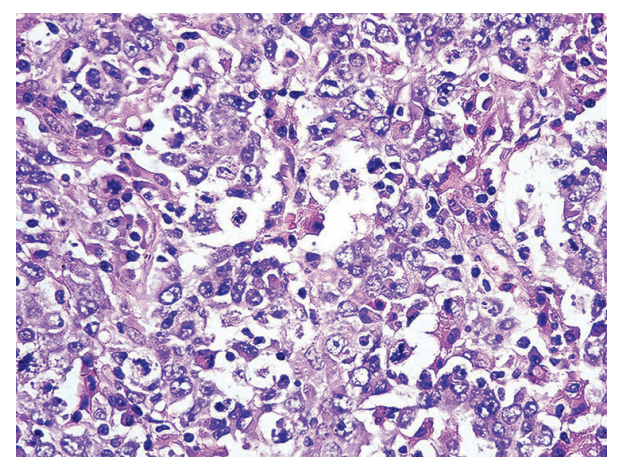

$3 c$

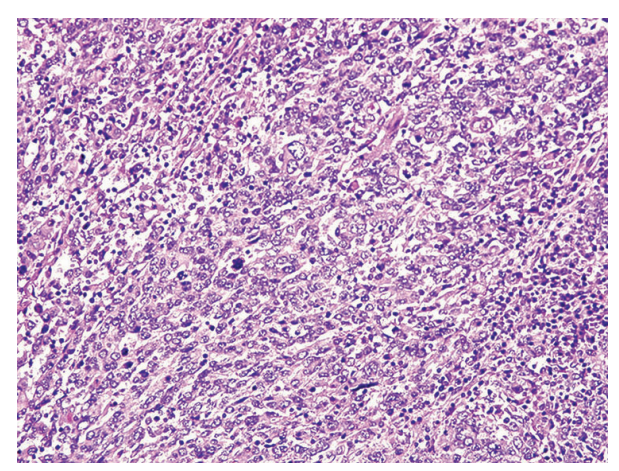

$3 b$

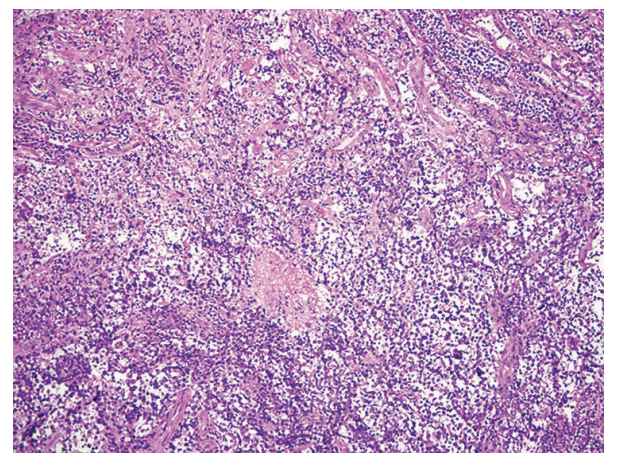

3d

Figure 3. Histology (H-E): a. A line of myometrium separates LCNEC (down, on the left) from the leiomyoma (magnification $\times 50)$; $\mathbf{b}$. Diffuse structure of LCNEC, with pathological mitosis - (magnification $\times 100)$; c. Predominance of cells with large oval vesicular nuclei with distinct nucleoli and pink cytoplasm, which fades into the cytoplasm of the adjacent cells. There are no gland structures, but at some places there are traces of nest-like structures (magnification $\times 400$ ); d. Outbreak necrosis regardless of the good vascularization of the tumor parenchyma (magnification $\times 100$ ).
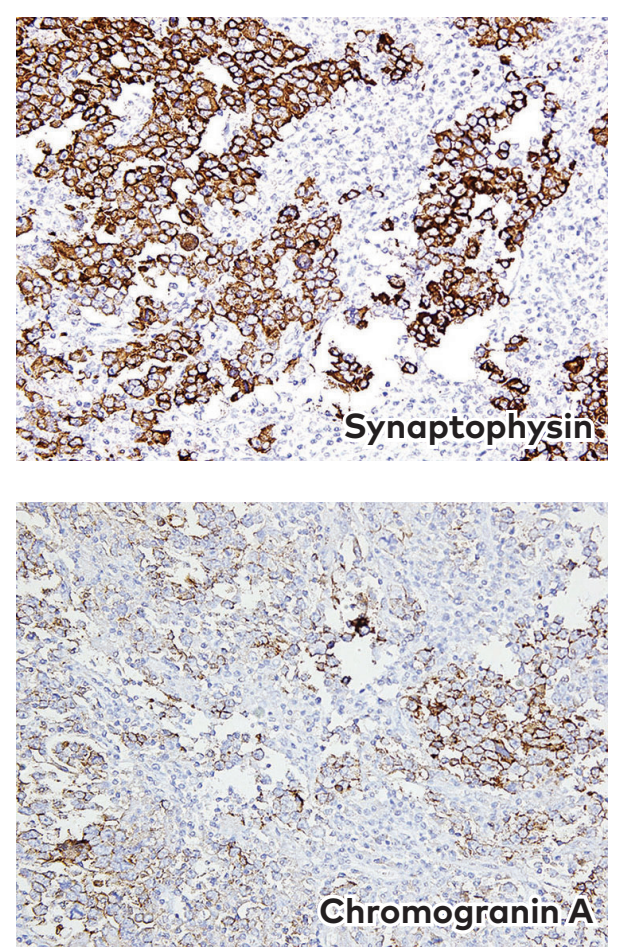
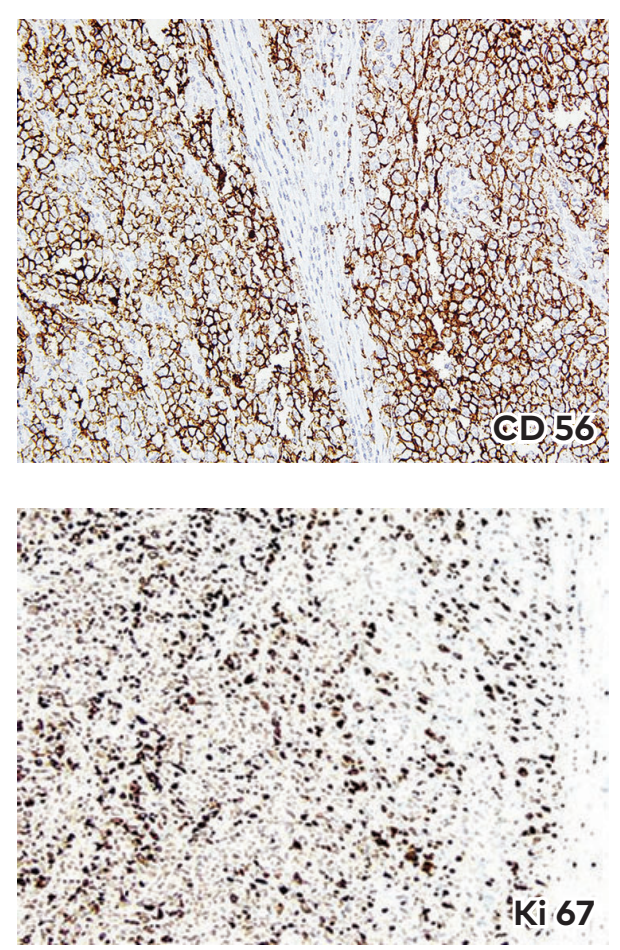

Figure 4. Immunohistochemistry of LCNEC: Positive expression of synaptophysin, CD56, chromogranin A; Ki 67 over 75\%. (magnification $\times 200$ ) 
CK5/6/7/8/18/20, EMA, HMB 45, S100, Melan A, Cyklin D1, ER, PAX8, and TTF1.

Diagnosis: Large-cell neuroendocrine carcinoma of the endometrium, FIGO IIIC; TNM: pT3, N1, MO.

Operative intervention, paraclinical and histological examinations were carried out at the MBAL Parvomai Ltd, Parvomai, Bulgaria.

Post-surgery course: The patient underwent three courses of chemotherapy with cisplatin and etoposide. Four lymph nodes with metastasis from LCNEC were found during dissection. The adjuvant therapy continued with three more courses of chemotherapy with cisplatin and etoposide. Eight months after the diagnosis was made the woman is in a sufficiently good condition without any clinical signs of relapse and distant metastasis.

\section{DISCUSSION}

Neuroendocrine tumors are less than $1 \%$ of the carcinomas of endometrium. ${ }^{10}$ This group includes low-grade neuroendocrine tumors, carcinoid tumors, and high-grade neuroendocrine tumors - LCNEC and other small cell neuroendocrine carcinomas (SCNEC, over 90 reported cases ${ }^{3,11}$ ). There have also been reports of large-cell carcinomas of the cervix, which, according to the common topical principle of WHO classification ${ }^{10}$, do not belong to the group of LCNEC of the endometrium.

The mean age of patients with LCNEC is 62 years. The main symptom is genital bleeding. In the majority of the studied cases, the tumor infiltrates over half of the myometrium, with manifested metastases in the pelvis and para-aortal lymph nodes at the moment of the diagnosis.

The histological characteristic of LCNEC in the endometrium comprises diffusional, trabecular, or cordlike structure, cellular polymorphism - large polygonal cells with large oval nuclei with grainy chromatin, distinct nucleoli and well-expressed cytoplasm, multinucleated cells and high mitotic activity, presence of a "geographical" necrosis and vascular invasion. ${ }^{2-5}$ In cases of LCNEC synaptophysin appears to act as a more sensitive immunohistochemical marker than chromogranin A, and CD 56 is not specific, because it also marks the conventional endometrial carcinomas of the uterus and ovaries. ${ }^{3}$

There are many factors connected with healthcare organization and diagnostic level that determine the varying FIGO-studying of the 38 known cases of LCNEC: stage 1 10 ; stage $2-3$; stage $3-17$; stage $4-9$ cases. ${ }^{2-9}$ The average survival rate is about 12 months, but it varies greatly from 1 month $^{9,11-13}$ to over 2 years ${ }^{4,5,11}$. No definitive treatment option can be recommended: with the chemotherapy of 10 patients (mainly platinum-based) the survival rate was 11 months, but relapses occurred; with independent radiation therapy (8 patients) the survival rate was 9 months. ${ }^{2}$

LCNEC of the endometrium has been reported in combination with other malignant tumors, mostly endometrial carcinomas. ${ }^{3,8,11}$ These cases, however, do not comply with the strict criteria for collision tumors. There has been only one documented combination of LCNEC and leiomyoma. ${ }^{6}$ In our case, the lack of infiltration in the benign tumor and its low growth potential show that their synchronicity is accidental.

Detection of neuroendocrine fraction in other malignant tumors of the uterus suggests that the set precursor cells in the endometrium undergo neoplastic transformation influenced by general factors or by paracrine regulation of the prevailing tumor component. The subjective quantitative criterion in assessing the neuroendocrine phenotype of the tumor (over $10 \%$ of the tumor cells) could entail differentially diagnostic difficulties especially in curettage materials and/or in cases of suspected primary origin in the cervix. When neuroendocrine markers are discretely positive, some histological characteristics can show decisive results. Carcinoid tumors possess a distinctive drawing. The lack of a mixed component does not support malignant mixed Mullerian tumor, and the lack of neuroectodermal differentiation (febrile background, rosettes, ganglia and astrocyte-like cells) excludes the option of primitive neuroectodermal tumor. The well-known image from the lung tumors with small lymphocyte-like or oat-like hyperchromic cells with insufficient cytoplasm (without intercellular bridges) and diffusion trabecular or rosette-like structure are typical for SCNEC of the endometrium, and the cervical SCNEC is 16 positive and is associated with HPV type 18. ${ }^{10}$ The immunohistochemical panel is then to be widened using also cyclin D1(+) - for excluding high-grade endometrial stromal sarcoma and the constellation HMB 45(-), EMA(-), CK AE1/AE3(-) excludes perivascular epithelioid cell tumor. CK $18(+)$ in about $35-40 \%$ is a sign of undifferentiated carcinoma. ${ }^{3}$

\section{CONCLUSIONS}

LCNEC of the endometrium is an insufficiently researched rare aggressive tumor with a short survival, regardless of the treatment type. In our case, its development in the myomatous uterus additionally hampers the diagnosis. The subjective quantitative criterion in assessing the neuroendocrine phenotype of the tumor, especially in curettage materials, could require distinction from other malignant blastomas of the endometrium, although it is with a small (less than $10 \%)$ neuroendocrine component. They can be excluded by discrete histological signs and via a comprehensive immunohistochemical panel. The described differential diagnosis plan would help distinguish LCNEC from other uterine tumors. Because of its high aggressiveness, this rare tumour should be well known entity not only to pathologists, but also to gynaecologists, oncologists and radiologists.

The accumulated clinical and morphological evidence should show more definitively whether the large-cell and the small-cell neuroendocrine carcinomas are just different variations according to their histology and topical occurrence (uterine body/cervix) or they are just independent 
forms with their respective clinical signs, morphology, treatment, and prognosis.

\section{REFERENCES}

1. Erhan Y, Dikmen Y, Yucebilgin MS, et al. Large cell neuroendocrine carcinoma of the uterine corpus metastatic to brain and lung: case report and review of the literature. Eur J Gynaecol Oncol 2004; 25:109-12.

2. Tu YA, Chen YL, Lin MC, et al. Large cell neuroendocrine carcinoma of the endometrium: A case report and literature review. Taiwan J Obstet Gynecol 2018; 57(1):144-9.

3. Pocrnich CE, Ramalingam P, Euscher ED, et al. Neuroendocrine carcinoma of the endometrium: a clinicopathologic study of 25 cases. Am J Surg Pathol 2016; 40:577-86.

4. Ono K, Yokota NR, Yoshioka E, et al. Metastatic large cell neuroendocrine carcinoma of the lung arising from the uterus: A pitfall in lung cancer diagnosis. Pathol Res Pract 2016; 212(7):654-7.

5. Ariura M, Kasajima R, Miyagi Y, et al. Combined large cell neuroendocrine carcinoma and endometrioid carcinoma of the endometrium: a shared gene mutation signature between the two histological components. Int Cancer Conf J 2016; 6(1):11-5.

6. Kobayashi A, Yahata T, Nanjo S, et al. Rapidly progressing large cell neuroendocrine carcinoma arising from the uterine corpus: A case report and review of the literature. Mol Clin Oncol 2017; 6(6):881-5.

7. Ieni A, Angelico G, De Sarro R, et al. Uterine large cell neuroendocrine carcinoma with unusual colonic metastasis. J Cancer Metastasis Treat 2017; 3:144-9.

8. Junainah EM, Huwait HF, Albezrah NKA, et al. Combined large cell neuroendocrine carcinoma and papillary serous carcinoma of the endometrium rare type with literature review. Biomedical Research 2017; 19: 8165-8.

9. Ogura J, Adachi Y, Yasumoto K, et al. Large-cell neuroendocrine carcinoma arising in the endometrium: A case report. Mol Clin Oncol 2018; 8(4): 575-8.

10. Kurman RJ, Carcangiu ML, Herrington CS, et al. WHO classification of tumours of female reproductive organs. Lyon: IARC Press; 2014: $131-2$.

11. Mulvany NJ, Allen DG. Combined large cell neuroendocrine and endometrioid carcinoma of the endometrium. Int J Gynecol Pathol 2008; 27:149-57.

12. Nguyen ML, Han L, Minors AM, et al. Rare large cell neuroendocrine tumor of the endometrium: a case report and review of the literature. Int J Surg Case Rep 2013; 4(8): 651-5.

13. Makihara N, Maeda T, Nishimura M, et al. Large cell neuroendocrine carcinoma originating from the uterine endometrium: a report on magnetic resonance features of 2 cases with very rare and aggressive tumour. Rare Tumours 2012; 4(3): e37. 


\title{
Крупноклеточная нейроэндокринная карцинома эндометрия при миоме матки
}

\author{
Спасимир Т. Шопов ${ }^{1}$, Бенямин Л. Анави ${ }^{2}$, Добрин К. Крастев ${ }^{3}$ \\ ${ }^{1}$ Кафедра общей и клинической патологии, Медицинский университет - Пловдив, Пловдив, Болгария, Отделение патологоанатомии, МБАЛ \\ - Первомай, Первомай, Болгария \\ ${ }^{2}$ Отделение патологии, СБАЛАГ „ТОРАКС Д-р Сава Бояджиев“, Пловдив, Болгария \\ ${ }^{3}$ Отделение акушерства и гинекологии, МБАЛ - Первомай, Первомай, Болгария
}

Автор для корреспонденции: Спасимир Т. Шопов, Кафедра общей и клинической патологии, Медицинский университет - Пловдив, бул. „Васил Априлов“ № 15A, 4000 Пловдив, Болгария; E-mail: sshopov1@abv.bg; тел.: 0878657256

Дата получения: 07 декабря 2018 Дата приемки: 1 августа 2019 Дата публикации: 30 июня 2020

Образец цитирования: Shopov ST, Anavi BL, Krastev DK. Large-cell neuroendocrine carcinoma of the endometrium in myomatous uterus. Folia Med (Plovdiv) 2020;62(2):412-17. doi: 10.3897/folmed.62.e49815.

\section{Резюме}

Крупноклеточная нейроэндокринная карцинома эндометрия представляет собой недостаточно изученную агрессивную опухоль с кратковременным выживанием независимо от типа лечения.

Здесь мы представляем 38-й последовательный случай, документированный в литературе, крупноклеточной нейроэндокринной карциномы эндометрия (положительной по синаптофизину, CD56, хромогранину А, p53 и виметину), обнаруженной в миоме матки 76-летней женщины.

В ходе исследования мы также описали морфологический алгоритм дифференцировки злокачественных бластом с небольшим (менее 10\%) нейроэндокринным компонентом.

Собранные клинические и морфологические данные поднимают вопрос о том, являются ли крупные и мелкоклеточные карциномы только различными вариациями в зависимости от их гистологии и местного проявления (тела матки и шейки матки) или являются отдельной формой с соответствующими клиническими признаками, морфологией, лечением и прогнозом.

\section{Ключевые слова}

иммуногистохимия, крупноклеточная нейроэндокринная карцинома эндометрия, миома матки 